\title{
A STUDY ON THE IMPLEMENTATION OF
}

SCHOOL BASED MANAGEMENT OF STATE OWNED

SCHOOLS OF SRI LANKA

WITH SPECIAL REFERENCE TO

THE NATIONAL SCHOOLS

By

PUSHPA SHIRANI YATAWARA

GS/MC/1860/2001

Thesis submitted to the Faculty of Graduate Studies, University of

Sri Jayewardenepura, Sri Lanka, in partial fulfilment of the requirement for the award of the Degree of Master of Science in Management, May 2007 


\section{DECLARATION OF THE CANDIDATE}

The work described in this thesis was carried out by me under the supervision of, Dr, Ananda Wickremasinghe, Senior lecturer in Business Strategy, Department of Business Administration, University of Sri Jayawardenapura, Nugegoda, Sri Lanka and a report on this has not been submitted in whole or in part to any university or any other institution for another Degree/ Diploma.

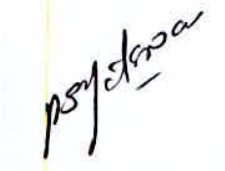

Pushpa Shirani Yatawara

GS/MC/1860/2001 
I hereby recommend that the thesis prepared under my supervision by,

Pushpa Shirani Yatawara

Entitled

'A study on the implementation of School Based Management of state owned schools of Sri Lanka, with special reference to the National Schools'

Be accepted in partial fulfilment of the requirement for the degree of Master of Science in Management.

\section{Thesis Advisor}

Approved by the examiners: ..............

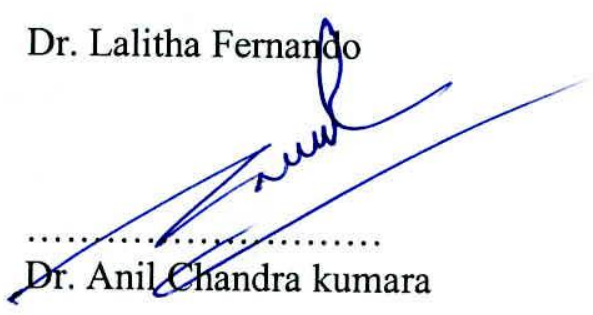

M.Sc. (Management) Programme

Faculty of Graduate Studies

University of Sri Jayawardenapura

Sri Lanka

May, 2007 


\section{TABLE OF CONTENTS}

\section{CONTENT}

PAGE NO.

CHAPTER ONE

01

1. INTRODUCTION 02

1.1 The problem background 02

1.2 Statement of the problem 04

1.3 Objectives of the study 06

1.4 Significance of the study 07

1.5 Scope \& Limitations of the study 08

1.6 Research Methodology in brief 09

$\begin{array}{lll}\text { 1.6.1 Sample } & 09\end{array}$

$\begin{array}{ll}\text { 1.6.2 Collection of data } & 10\end{array}$

1.6.3 Analyses of data 11

1.7 Organization of the study 12

1.8 Chapter summary 13

CHAPTER TWO

2. REVIEW OF LITERATURE 15

$\begin{array}{lll}2.1 & \text { Introduction } & 15\end{array}$

2.2 International perspective of School Based Management 15

2.3 Terms \& Definitions 17

2.3.1 School Based Management (SBM) 17

2.3.2 Decentralization, Accountability \& Devolution 20 
2...4 History of School Based Management Reforms in Sri Lanka

2.4.1 Seminal role of Kannangara Report (1943) 22

2.4.2 Education Reforms Committee 23

2.4.3 School Development Boards 25

2.4.4 Reforms in General Education 26

2.5 Objectives \& outcomes of SBM as mentioned in the circular 30

2.6 The Administrative Structure at school level 32

2.7 Other Landmarks in Research 33

$\begin{array}{lll}2.8 & \text { Obstacles to success } & 38\end{array}$

2.9 Chapter summary 41

CHAPTER THREE 43

3. CONCEPTUAL FRAME WORK 44

$\begin{array}{lll}3.1 & \text { Introduction } & 44\end{array}$

3.2 The conceptual model 44

$\begin{array}{lll}3.3 & \text { The Hypotheses } & 46\end{array}$

$\begin{array}{lll}3.4 & \text { Conceptualization of variables } & 47\end{array}$

$\begin{array}{lll}3.5 & \text { Chapter summary } & 56\end{array}$

$\begin{array}{lr}\text { CHAPTER FOUR } & \mathbf{5 7}\end{array}$

4. THE METHODOLOGY 58

$\begin{array}{llr}4.1 & \text { Introduction } & 58\end{array}$

$\begin{array}{lll}4.2 & \text { The Research Design } & 58\end{array}$

$\begin{array}{lll}4.3 & \text { The Sample } & 58\end{array}$ 
$\begin{array}{ll}4.4 & \text { Collection of Data }\end{array}$

$\begin{array}{lll}4.5 & \text { The questionnaire } & 61\end{array}$

4.6 The reliability test of variables 64

$\begin{array}{lll}4.7 & \text { Analysis of data } & 64\end{array}$

$\begin{array}{lll}4.8 & \text { The rejection criteria } & 66\end{array}$

4.9 Limitations of the research 66

$\begin{array}{lll}4.10 & \text { Chapter summary } & 68\end{array}$

$\begin{array}{ll}\text { CHAPTER FIVE } & 69\end{array}$

5. ANALYSIS AND DISCUSSION OF EMPIRICAL FINDINGS 70

$\begin{array}{lll}5.1 & \text { Introduction } & 70\end{array}$

5.2 Descriptive analyses of the questions with relevant to concepts $\quad 70$ and variables:

$\begin{array}{lll}\text { 5.2.1 Level of Perception } & 70\end{array}$

$\begin{array}{lll}\text { 5.2.2 Expectations } & 83\end{array}$

$\begin{array}{lll}5.2 .3 & \text { Strategies } & 95\end{array}$

$\begin{array}{lll}5.2 .4 \text { Constraints } & 100\end{array}$

$\begin{array}{lll}5.3 & \text { Testing hypotheses } & 104\end{array}$

$\begin{array}{lll}5.4 & \text { Results revealed from unstructured interviews } & 109\end{array}$

$\begin{array}{lll}5.5 & \text { Chapter summary } & 111\end{array}$

$\begin{array}{lr}\text { CHAPTER SIX } & 114\end{array}$

6. CONCLUSIONS AND SUGGESIONS 115 
$\begin{array}{lll}6.1 & \text { Introduction } & 115\end{array}$

$\begin{array}{ll}\text { 6.2 Findings of the research } & 116\end{array}$

$\begin{array}{llr}6.3 & \text { Suggestions } & 121\end{array}$

$\begin{array}{lr}\text { REFERENCES } & 124-125\end{array}$

\section{APPENDICES}

01 The Questionnaire (English) $126-133$

02 The Questionnaire (Sinhala translation) $134-141$

03 The Circular on Programme on School Improvement 142 


\section{LIST OF TABLES \& FIGURES}

TABLE No.

PAGE No.

1.1 Distribution of National Schools according to Gender

$\&$ Medium of instruction

3.1 Conceptualization in summary 51

$\begin{array}{lll}4.1 & \text { Distribution of the Sample across provinces } & 60\end{array}$

5.1 Awareness 'Programme on School Improvement' 71

$\begin{array}{lll}5.2 & \text { Formation of SDC } & 72\end{array}$

$\begin{array}{lll}5.3 & \text { Formation of SMT } & 72\end{array}$

$\begin{array}{lll}5.4 & \text { SDC meetings conducted } & 73\end{array}$

$\begin{array}{lll}\text { 5.5 Briefed on the authority delegated } & 73\end{array}$

$\begin{array}{lll}5.6 & \text { School issues Discussed } & 74\end{array}$

$\begin{array}{lll}5.7 & \text { Areas discussed } & 74\end{array}$

$\begin{array}{lll}5.8 & \text { Preferred qualities by the principals } & 77\end{array}$

$\begin{array}{lll}5.9 & \text { Satisfaction with the level of authority } & 78\end{array}$

$\begin{array}{lll}5.10 & \text { Principals given a training on SBM } & 79\end{array}$

5.11 Number of members in SDC 80

5.12 Percentage of participation for SDC meetings 81

5.13 Contribution of SDC members $\quad 82$

5.14 Sufficiency of authority delegated 83

$\begin{array}{lll}5.15 & \text { Comparatively more authority delegated } & 84\end{array}$

5.16 Preferred areas of authority $\quad 85$

$\begin{array}{lll}5.17 & \text { Preferred authority over teachers } & 87\end{array}$

5.18 Circulars that need to be amended 88

5.19 Expected competencies of SDC members 90

5.20 Decision making power on utilization of resources 92

5.21 Contribution towards formulation of 5-year plan 9

5.22 Contribution towards formulation of annual operational plan 97

5.23 Strategies identified 97

5.24 Inclusion of fund raising projects in the annual operational plan 98 
TABLE No.

PAGE No

5.25 Access to financial information 98

5.26 Utilization of resources 99

$\begin{array}{ll}5.27 \text { Constraints for successful implementation of SBM } & 101\end{array}$

$\begin{array}{lll}5.28 & \text { SBM an unnecessary burden } & 102\end{array}$

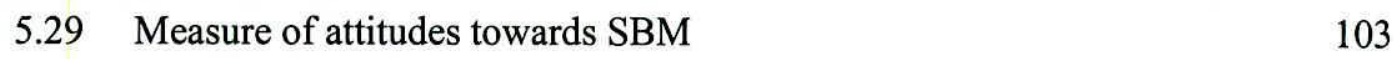

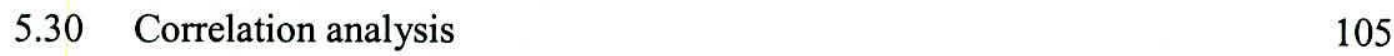

$\begin{array}{ll}5.31 \text { Correlations of the variables } & 106\end{array}$

$\begin{array}{ll}\text { FIGURE No. } & \text { PAGE No. }\end{array}$

3.1 The relationship among Perception and Strategies, Expectations, Constraints. $\quad 44$

4.1 Methods used for collection of Primary Data 61

$\begin{array}{lll}5.1 & \text { Priorities given to the areas discussed }\end{array}$ 


\section{ACKNOWLEDGEMENTS}

I take this opportunity to convey my grateful and sincere thanks to my Supervisors, Dr. Ananda Wickremasinghe, Senior lecturer in Business Strategy, Department of Business Administration, University of Sri Jayawardenapura, and also Mrs. M.D. Pushpakumari, Senior lecturer, Department of Business Administration, University of Sri Jayawardenapura, who was my supervisor initially but had to leave the country for higher studies before the completion of my work, for their constant guidance and encouragement offered so very readily.

My appreciation is also extended to Mr. A.G.M.M.N.S.P. Molligoda, Senior lecturer, Department of Business Administration, University of Sri Jayawardenapura, who helped me with the editing of my work within a very short time and also for the guidance given to me.

I also express my gratitude to the co-ordinator, M.Sc. Management Degree programme, Dr. P.D. Nimal and the previous coordinators, Dr. Sampath Amarathunga, Professor H.H.D.N.P. Opatha and Dr. (Mrs.) Badra Arachchige, for the support given so readily at all times.

My very special thanks are extended to Dr. (Mrs.) Lalitha Fernando and all the lecturers in the M.Sc. Management Degree programme for their encouragement and support.

Finally my appreciation is extended to my colleagues who helped me in every possible way to make this thesis a success. 


\title{
A STUDY ON THE IMPLEMENTATION OF
}

\author{
SCHOOL BASED MANAGEMENT OF STATE OWNED SCHOOLS OF
}

\author{
SRI LANKA
}

WITH SPECIAL REFERENCE TO THE NATIONAL SCHOOLS

\begin{abstract}
During the past several years, the educational systems in most countries have been evolving from largely centralized structures to more decentralized ones and although the main expression of this trend goes by different names, it is often called School-Based Management. (SBM). In Sri Lanka the Ministry of Education has been trying to implement SBM since the year 1997.

In the year 2005, a circular was sent out from the Ministry of Education with regard to implementation of SBM and this was called 'A pilot Programme on School Improvement' The relevant circular, requested the principals to establish School Development Committees (SDC) and School Management Teams (SMT) before $31^{\text {st }}$ July 2005. The SMT would be a sub-committee appointed by the principal to implement the decisions taken by the SDC.

The responsibilities of the SDC would be planning and make decisions with regard to implementation of these plans including the five year school plan and the annual operational plan. These plans are supposed to consist of activities that are focused on the teachinglearning process, co-curricular activities, teacher development and maintenance and development of the school environment.

This research is focussed on whether the members of the School Development Committee (SDC) perceived their new mandate, what are the expectations of the School Development Committees with regard to developing their school?, what strategies have the SDC members adopted to achieve their expectations with regard to development of the school? And what are the constraints that prevent School Based Management being implemented in the schools?

Four main objectives were also developed associated with the above research questions, which are; to explore the correlation between the competencies of the SDC members and their commitment, to explore the correlation between the commitment and the decision making power of SDC members in utilization of resources, according to needs identified by the school, to see the correlation between the competencies of SDC members and the degree of utilization of resources according to needs identified by the school and to explore the correlation between the resistance to change of SDC members and their commitment.
\end{abstract}


The sample selected for this research was fifty four National schools distributed through out the country. Data was mainly collected through a questionnaire that was sent to the principals of the selected schools to be filled in consultation with the SDC members of their schools.

Data were analysed using SPSS version 13. The categorised data were analysed through frequencies and percentages and are presented descriptively through tables, charts and graphs. Hypotheses were tested through correlation analysis. The ranked variables were analyzed by comparing means of the ranks, under each option given. To measure attitudes a 1 to 5 scale was used and the analysis was carried out by the comparison of mean values.

It was revealed through the research that the level of perception is at a satisfactory level. Although the principals seemed to be happy with the authority delegated through SBM their expectations were not fully met. There seemed to be more areas where they anticipate a delegation of authority. The schools had formulated strategies to utilize available resources to fulfill the identified requirements of the school but it was also revealed that mostly these plans were formulated by one or two persons in the school. The constraints for the implementation of SBM in schools were identified as rigid outdated financial rules and regulations, the peoples' unwillingness to change their attitudes and political interference. But these constraints could be overcome to a certain extent through the adoption of proper strategies as suggested by the researcher in the final chapter.

With regard to the hypotheses formulated for the objectives only for the first hypotheses $\mathrm{H}_{1}$ was accepted and for all other hypotheses Ho was accepted.

It was confirmed $\left(\mathrm{H}_{1}\right)$ that there is a positive correlation between the level of competencies and the amount of commitment of SDC members, towards formation of school policy and strategies. It also confirmed (Ho) that there is no significant correlation between the level of commitment of SDC members and utilization of resources according to needs identified by the school. With regard to the third hypotheses it confirmed that (Ho) there is no significant correlation between the levels of competencies of SDC members and the degree of utilization of resources according to needs identified by the school. It also confirmed that (Ho) there is no significant correlation between the variables 'level of resistance to change' and the 'commitment of SDC members in formulation of school policy and strategies'. 


\section{CHAPTER ONE}




\section{INTRODUCTION}

\subsection{The problem background}

In most countries, educational planners and administrators have focused their attention on re-positioning of existing power or authority and responsibilities away from central governments towards local communities. This trend is expressed as 'decentralization' process which has moved decision- making power closer to schools in domains, which have included certain aspects such as curricula determination, financial allocations, usage of resources, student assessment procedures and staffing decisions. (Wohlstetter and Mohrman, 1993)

The most extreme forms of this re-alignment of power (authority) and responsibilities were associated with the restructuring of public education systems, into networks of self managing schools that are organized around centralized policy guidelines, combined with school level autonomy for the management of the educational environment and the development of resources.

This reform of educational administration is described under the general heading of ' School Based Management' (SBM). Many developed countries have instituted School-Based Management in the structure of educational governance. Interest in such a reform is currently spreading to other parts of the world, including developing countries. 
Although many bodies both national and international are encouraging the implementation of School-Based Management with the intention of increasing efficiency and effectiveness of school education, this is still subjected to argument. Whether School Based Management is necessary to improve equity, social justice or equality of educational opportunity, is yet to be reconsidered. Many researchers now emphasize the importance of strong school leadership, as well as community and parental involvement in improving school effectiveness. (Edmund 1998) It is stated in the National Education Commission report of December 2003 (p.65) that

"The National Education Commission reiterated in its policy documents since 1993 that schools should function as self managing units within regulations formulated by the government. The General Education Reform (1997) made a specific recommendation that School Based Management should be introduced to make schools function more efficiently. It was envisaged that the principal should be a leader with authority to manage the schools with the assistance of a School Board and teachers, to develop a school policy and programme that interact with the school community.

The National Institute of Education was assigned the task of organizing training programmes to equip educational personnel with the competencies necessary for School Based Management."

The Sri Lankan Ministry of Education has now decided to implement School Based Management as a Pilot project called 'Programme on School Improvement, (PSI)' in a selected sample of schools from year 2006. This sample consists of 08 Education zones, selected one from each of the 08 provinces, 388 Navodya Schools which are provincial schools developed through a special project, 54 Central Schools established by the Honourable C.W.W. Kannangara that are also within the purview of the Provincial Councils, and 324 National Schools that are within the purview of the line Ministry of Education. 